\title{
PRIMENA NOVE GENERACIJE METODA ZA SEKVENCIRANJE DNK (NEXT GENERATION SEQUENCING) U MEDICINSKOJ PRAKSI
}

\author{
Ivana Novaković ${ }^{1}$
}

${ }^{1}$ Medicinski fakultet Univerziteta u Beogradu

Sažetak

Analize genetičkog materijala imaju svoju primenu u medicinskoj praksi već više decenija. Medicin ska genetika raspolaže širokim spektrom metoda, od klasične citogenetičke obrade kariotipa radi uočavanja numeričkih i strukturnih aberacija hromozoma, do najfinijih ispitivanja za detektciju genskih mutacija na molekularnom nivou. Poslednjih godina razvijaju se potpuno nove metode za brzu, efikasnu i dostupnu analizu naslednog materijala, koje su poznate kao "next generation sequencing” (NGS) ili nova generacija metoda za sekvenciranje DNK. Ove metode omogućavaju ispitivanje ne samo pojedinačnih gena ili delova gena nego $i$ većeg broja segmenata, sve do kompletne nasledne osnove tj. čitavog genoma čoveka. Primena ovakvog pristupa dovodi do prave „tihe revolucije” u medicinskoj genetici i disciplinama sa kojima ona sarađuje, nagoveštavajući promenu u konceptu dijagnostike naslednih i drugih poremećaja, kao i predispozicija. U prenatalnoj dijagnostici NGS je već našla primenu u potpuno neinvazivnoj detekciji najčešćih hromozomskih aberacija (Daunov, Edvardsov, Patau sindrom, aberacije polnih hromozoma) analizom fetalne DNK prisutne u krvi majke. Komercijalni testovi za ovaj tip analize su dostupni i trudnicama u našoj sredini. U postnatalnom periodu NGS se koristi za ispitivanje odabranih gena, panela gena, pa do čitavog genoma/egzoma, a sa ciljem što efikasnije dijagnostike pre svega monogenskih, ali i multifaktorskih bolesti. NGS ima primenu u oblasti farmakogenetike, koja je važan korak u razvoju presonalizovane medicine XXI veka. Predlaže se čak da analiza kompletnog genoma postane deo neonatalnog skriniga, ali za sada to nije prihvaćeno. Nesumnjivo je da rezultati NGS donose veliki napredak medicinsko-genetičkoj praksi, ali i rađaju nove etičke dileme i pitanja.

Ključne reči: nasledni poremećaji, dijagnostika i intervencija, nove metode

\section{Abstract}

Analyses of genetic material are available in medical genetic practice for decades. Methods are ranged from cytogenetic karyotype analysis for processing numerical and structural chromosomal aberrations, by sophisticated examination of gene mutations on molecular level. In recent years new methods have been developed for rapid and efficient analysis of genetic material, known as the "next generation sequencing" (NGS). These methods allow examination not only individual genes or parts of genes but also a larger number of segments, up to complete inherited basis i.e. the entire human genome research. Implementation NGS approach leads to "silent revolution" in medical genetics and disciplines with which it co-operate, suggesting a change in the concept of diagnosis of inherited and other disorders. In prenatal diagnostics NGS has already found application in completely noninvasive detection of chromosomal aberrations (Down, Edwards, Patau syndrome, sex chromosomes aberrations) by analysis of fetal DNA in mother's blood. Such tests are available for pregnant women in Serbia also. In postnatal period NGS is used for the examination of selected genes, gene panels, up to entire genome/exome analysis, all with the aim to improve the diagnostics not only of primarily monogenic, but multifactorial disorders also. NGS could be applied in pharmacogenetic testing also, which is important step to realize 21 st century's personalized medicine. It is proposed that the analyses of the complete genome become part of neonatal screening, but this has not been, yet, accepted. It is undeniable that the results of NGS make a great progress in medical - genetic practice, but gained new ethical dilemmas and questions.

Key words: hereditary disorders, diagnosis and intervention, new methods 


\section{Uvod}

Poslednje decenije obeležene su burnim razvojem molekularne genetike, i njenom primenom u svim biomedicinskim i srodnim disciplinama. Osamdesetih godina prošlog veka identifikovani su prvi geni odgovorni za monogenske bolesti čoveka (cistična fibroza, Dišenova mišićna distrofija) i razvijena je metoda PCR (lančana reakcija polimerizacije DNK), kao i automatsko sekvenciranje metodom po Sangeru . To je bio uvod u devedese godine, koje su obeležene realizacijom Projekta genoma čoveka, kao do sada najvećeg internacionalnog naučnog projekta. Sa početkom novog milenijuma objavljena je prva kompletna verzija humanog genoma, i dobijni podaci su potom povezani sa brojnim fiziološkim karakteristikama i patološkim stanjima kod čoveka. Danas znamo za više od 4000 gena koji su odgovorni za pojedine monogenske poremećaje (poremećaji uslovljeni mutacijom u jednom genu), a za većinu njih postoje razvijeni testovi ze prenatalnu ili postnatalnu dijagnostiku. U oblasti poligenskih tj. multifaktorskih poremećaja, koji nastaju u sadejstvu nasledne osnove i spoljašnjih činilaca, intenzivno se proučavaju genetički markeri podložnosti, sa idejom rane identifikacije rizika i prevencije poremećaja. Narastajuća znanja iziskujui nove metode za analizu naslednog materijala. Osnovni zahtev je da te metode budu tehnički i ekonomski dostupne što širem krugu zainteresovanih, a da sa druge strane obezbede integrativno sagledavanje velikog broja gena i njihovih međusobnih interakcija [1].

Upravo na toj ideji započeo je razvoj nove generacije metoda za sekvenciranje DNK, poznatih kao "next generation sequencing" (NGS). Generalno, sekvenciranjem se određuje primarna struktura tj. tačan redosled nukleotida u molekulu DNK. Gotovo četiri decenije koristi se pomenuta metoda sekvenciranja po Sangeru, koja se odlikuje izvarednom preciznošću, ali se može primeniti na segmene DNK realativno male dužine (ispod 1000bp). To je čini pogodnom za analizu pojedinačnih gena ili delova gena, ali ne i većih celina nasledne osnove. Imajući u vidu da je veličina humanog genoma preko tri milijarde baznih parova, njegovo sekvenciranje Sangerovom metodom za pojedinu osobu bi potrajalo mesecima. Nove metode se zasnivaju na ideji o paralelnom sekvenciranju velikog broja segmenata DNK (masovno paralelno sekvenciranje) i potom bioinformatičkom povezivanju dobijenih podataka. NGS ne bi bio moguć bez izuzetno razvijene tehničke i informatičke podrške. Upravo se obilje generisanih informacija pokazalo kao jedno od glavnih potencijalnih „uskih grla" ali i izazova ove metodologije (2). Tokom proteklih nekoliko godina više kompanija ponudilo je platforme za NGS, koje se zasnivaju na različitim idejama i biohemijskim principima. Neki od aparata koji su trenutno aktuelni su Ion Torrent (Life sci. Technology), HiSeqi MiSeq (Illumina), ali je tržište izuzetno dinamično i živo. Napomenućemo da su među pionirima NGS pristupa eminentni i svetski priznati molekularni biolozi R. Drmanac i R. Crkvenjakov, obojica potekli sa Beogradskog univerziteta.

\section{Principi primene NGS metodologije u medicinskoj genetici}

Korak po korak došlo se do granice snova, da je moguće sekvenciranje jednog humanog genoma uraditi za par dana, po ceni nižoj od 5000 evra. U međuvremenu razvili su se različiti pravci primene NGS. Pored analize čitavog genoma, predlaže se i analiza samo protein-kodirajućih regiona, tj. egzoma. Budući da egzom čini svega $1 \%$ naše nasledne osnove, ovakav pristup se čini racionalnim i opravdanim u mnogim slučajevima (3). Dizajnirane su i baterije za istovremeno sekvenciranje određenog seta gena - tzv. genski paneli. Paneli mogu da budu koncipirani šire ili uže, prema problematici tj. prema difrencijalnodijagnostičkim opcijama. U poslednje vreme u praktičnoj primeni se afirmisao panel koji sadrži kodirajuće regione - egzone 4813 gena, a to su svi geni koji su sada direktno povezani sa određenim kliničkim fenotipovima. Ovaj panel poznat je kao „klinički egzom“, što jasno govori o njegovom značaju za kliničku medicinu.

\section{NGS i monogenski poremećaji}

Metodologija NGS omogućava analizu gena za koje se već zna da su odgovorni za pojedine monogenske bolesti, ali i identifikaciju novih odgovornih gena i njihovih mutacija. Za svaku promenu detekovanu NGS metodom neophodna je potvrda klasičnim sekvencira njem po Sangeru, ali je procenat lažno pozitivnih nalaza izuzetno nizak.

Jedan od dobrih primera primene NGS su poremećaji sluha, koji su u 50-60\% slučajeva genetički uslovljeni. Kod nesindromske gluvoće nasleđivanje je uglavnom autozomno recesivno ( $80 \%$ porodica), i mada mutacije načešće pogađaju gene za koneksin 26 i koneksin 30, poznato je više od 60 odgovornih gena. Sindromska gluvoća postoji u okviru više od 400 sindroma, od kojih je najčešći Penderton sindrom. Objavljen je veći broj radova sa rezultatima sekvenciranja čitavog egzoma u porodicana sa gluvoćom, i do sada je ovom metodom identifikovano više od 15 novih gena kako za sindromske, tako i za nesindromske slučajeve (3). U jednom istraživanju su analizirani egzomi 20 porodica sa autozomno-recesivnom gluvoćom koje su bile negativne na koneksin 26 mutacije. Kod 12 porodica nađeno je 12 retkih homozigotnih 
mutacija u drugim genima, što je potvrdilo opravdanost ovog pristupa (4).

Oblast mentalne retardacije je takođe veliko polje za primenu NGS. Pored detekcije mutacija u već poznatim genima i kod sindromskih i kod nesindromski formi, sekvenciranje celog egzoma je dovelo do identifikacije oko 25 novih odgovornih gena (3).

Navešćemo i sopstveno iskustvo u analizi čitavog genoma kod porodice iz Srbije sa idiopatskom kalcifikacijom bazalnih ganglija (IKBG, Farov sindrom). Zahvaljujući međunarodnoj saradnji, kod naše porodice i kod još 5 porodica iz različitih regiona sveta otkrivene su mutacije u genu za trombocitni faktor rasta (PDGFB), koji do tada nije povezivan sa IKBG. Funkcionalne analize genske ekspresije potvrdile su ulogu PDGFB u patogenezi bolesti (5). Nakon toga, u različitim inostranim laboratorijama su analizom egzoma detektovane mutacije kod naših porodica sa kavernoznom malformacijom krvnih sudova mozga (CCM2 gen), autozomno recesivnom ataksijom (ANO10 gen) i dr. Pre godinu dana je i u Srbiji nabavljena prva platforma za NGS (Institut za molekularnu genetiku i genetičko inžinjerstvo, Beograd).

\section{NGS i hromozomske aberacije}

Naizgled neočekivano, NGS metodologija je našla primenu i u detekciji hromozomskih aberacija. Već je postala realnost prenatalna detekcija hromozomskih aberacija analizom fetalnih ćelija koje su prisutne u krvi majke. Metoda NGS omogućava otkrivanje najčešćih hromozomskih aberacija (trizomija 21, 18 i 13, aneuploidije polnih hromozoma) ovom potpuno neinvazivnom metodom. Komercijalni testovi, kao što je NIFTY dostupni su trudnicama i u našoj sredini, sa napomenom da se sama analiza vrši $u$ inostranim centrima. Objavljena su iskustva preko 900 prenatalnih dijagnostika koje su urađene pararelno NIFTY testom i klasičnom kariotipizacijom nakon amniocenteze (6). Za trizomije autozoma senzitivnost NIFTY testa je bila 100\% a specifičnost $99,9 \%$, a za aneuploidije polnih hromozoma senzitivnost je iznosila $85,7 \%$, a specifičnost $99,9 \%$. U detekciji trizomije hromozoma 21 i 13 postignuto je apsolutno poklapanje NIFTY i standardne metode, dok su nađeni pojedinačni lažno pozitivni nalazi trizomije 18 i lažno negativne monozomije $\mathrm{X}$ hromozoma. U svakom slučaju, pozitivan nalaz NIFTY testa mora da se potvrdi klasičnom analizom kariotipa. Takođe, napominjemo da NIFTY nije u potpunosti pouzdan kod višeplodnih trudnoća.

\section{NGS, farmakogenetika i farmakogenomika}

Farmakogetika je relativno nova grana medicinske genetike, koja se bavi uticajem nasledne osnove na različiti odgovor ljudi na terapiju. Dobro je poznato da isti lek, u istoj dozi, može da pokaže čitav raspon dejstva, od optimalnog, preko izostanka delovanja, do neželjenih posledica, uključujući i najteže komplikacije. Procenjuje se da oko 50\% pacijenata ne reaguje na terapiju tricikličnim antidepresivima, a oko $30-35 \%$ ne reguje na terapiju beta blokatorima ili statinima (7). Sa druge strane, samo u Sjedinjenim Amaričkim Državama godišnje ima preko 2,000.000 hospitalizacija zbog neželjenog dejstva lekova, a oko 100.000 je sa smrtnim ishodom. Farmakogenetika proučava povezanost varijacija u naslednoj osnovi čoveka sa navedenim različitim odgovorom na terapiju. Poznato je da je u genomu čoveka barem svaki hiljaditi nukleotid polimorfan, $t j$. da se razlikuje između dve osobe i dva lokusa. Ovi DNK polimorfizmi svakako imaju uticaja na metabolizam lekova (farmakodinamiku i farmakokinetiku), ali i na građu ciljnih proteina za koje se lekovi vezuju. Do sada je opisan veliki broj DNK polimorfizama koji su značajni za primenu pojedinih lekova, uključujući različite antihipertenzive, antidepresive, citostatike, antikoagulantnu i aniti-HIV terapiju i drugo. Treba se podsetiti da je citohrom P450 možda najznačajniji kompleks enzima koju učestvuju u metabolizmu lekova; na primer, CYP2D6 učestvuje u metabolizmu preko $25 \%$ lekova (7). NGS metodologija ima svoju primenu i u ovoj oblasti. Podaci koji se dobijaju ,isčitavanjem” čitavog genoma ili egzoma čoveka NGS metodologijom sadrže i varijante u CYP genima, i $\mathrm{u}$ drugim genima sa dokazanim i poznatim značajem $\mathrm{u}$ farmakogenetici. Moguće je i kreiranje posebnih farmakogenetičkih panela (CYP i drugi geni) za analizu NGS metodom. Ovo je posebno značajno budući da su danas upravo farmakogenetički testovi najšire primenjivana ispitivanja u medicinskoj genetici, i da je svaki pojedinac potencijalni korisnik ovih testova, koji su pravi primer personalizovane medicine XXI veka (6).

\section{Zaključak}

Nesumnjivo je da rezultati NGS donose veliki napredak medicinsko-genetičkoj praksi, ali i rađaju nove etičke dileme u oblasti rane detekcije naslednih poremećaja i intervencije kod ovih stanja. Predlaže se čak da analiza kompletnog genoma postane deo neonatalnog skriniga, ali za sada to nije prihvaćeno. 


\section{Reference}

1. Novakovic I, Maksimovic N, Pavlovc A, Zarkovic M, Rovcanin B, Mirkovic D et al.: An introduction to molecular genetic diagnostics. Journal of Medical Biochemistry, 2014;33:3-7

2. Schuster S: Next generation sequencing transforms today’s biology. Nature Methods, 2008;5:16-18

3. Rabbani B, Tekin M and Mahdich N: The promise of whole genome sequencing in medical genetics. Journal of Human Genetics, 2014;59:5-15

4. Diaz-Horta O, Duman Foster J, Sirmaci A, Gonzalez M, Mahdieh $\mathrm{N}$ et al.: Whole-exome sequencing efficiently detects rare mutations in autosomal resessive nonsyndromic hearing loss. PlosOne, 2012;7:e50628
5. Keller A, Westenberger A, Sobrido MJ, García-Murias M, Domingo AR, Sears RL et al.: Mutations in the gene encoding PDGF-B cause brain calcifications in humans and mice. Nature Genetics, 2013;45:1077-1082

6. Jiang F, Ren J, Cheng F, Zhou Y, Xsie J, Dan S et al.: Noninvasive Fetal Trisomy (NIFTY) test: an advanced noninvasive prenatal diagnosis methodology for fetal autosomal and sex chromosomal aneuploidies. MBC Medical Genomics, 2012;5:57-67

7. Novaković I, Maksimović N, Cvetković D: Pharmacogenetics and the treatment of thrombophilia. u: Pregnancy Thrombophilia - The Unsuspected Risk, ed. P. Ivanov, InTech, 2013 